Annex

Contents Volume I

Climate Change: International Law and Global Governance Volume I: Legal Responses and Global Responsibility

FOREWORD

PREFACE 11

ACKNOWLEDGEMENTS 13

THE EDITORS 15

THE CONTRIBUTORS 17

PART I: INTERNATIONAL CLIMATE CHANGE LAW A NEW LEGAL DISCIPLINE?

1 Intersections of Law and Cooperative Global Climate Governance - Challenges in the Anthropocene

Oliver C. Ruppel

2 Whose Climate, which Ethics? On the Foundations of Climate Change Law

Johan Hattingh

3 Legal Strategies to Come to Grips with Climate Change Jaap Spier

4 Climate Change Law: Objectives, Instruments and Structures of a New Area of Law

Hans-Joachim Koch

\title{
PART II: CLIMATE CHANGE AND HUMAN RIGHTS
}

5 Climate Change and Human Rights 203 Christian Roschmann

6 Economic, Social and Cultural Rights and Climate Change Ariranga G. Pillay 
7 Climate Change Adaptation and Human Rights: An Equitable View

Margaux J. Hall \& David C. Weiss

8 Climate Change and Human Rights: What Follows for Corporate Human Rights Responsibility?

Stefanie Ricarda Roos

9 Climate Change and Gender Justice: International Policy and Legal Responses

Patricia Kameri-Mbote

10 Climate Change and Children's Rights: An International Law Perspective

Katharina Ruppel-Schlichting, Sonia Human \& Oliver C. Ruppel

\section{PART III: CLIMATE CHANGE, TRADE, INVESTMENT AND REGIONAL INTEGRATION}

11 Climate, Trade and Investment Law in the Global Green Economy Markus W. Gehring \& Jarrod Hepburn

12 Two Stories about EU Climate Change Law and Policy Navraj Singh Ghaleigh

13 The Emissions Trading System in the Context of Climate Change: China's Response

Tianbao Qin

14 Climate Change, Human Security and Regional Integration: The Example of the Southern African Development Community Oliver C. Ruppel \& Katharina Ruppel-Schlichting

\section{PART IV: CLIMATE CHANGE, THE LAW OF THE SEA AND SEA-LEVEL RISE}

15 Climate Change Challenges and the Law of the Sea Responses Guifang (Julia) Xue

16 Holding Back the Waves? Sea-level Rise and Maritime Claims Clive Schofield 
17 Disappearing States: Harnessing International Law to Preserve Cultures and Society

Gregory E. Wannier \& Michael B. Gerrard

18 Climate Change and Small Island Claims in the Pacific

Yukari Takamura

PART V: JUDICIAL REVIEW AND INTERNATIONAL CLIMATE CHANGE LITIGATION

19 Some Perspectives on Global Governance, Judicial Review and Climate Change

Hennie A. Strydom

20 Climate Change, Global Governance and International Criminal Justice

Gerhard Kemp

21 Climate Change Litigation: A Global Tendency

Noriko Okubo

22 International Climate Change Cases

Roda Verheyen \& Cathrin Zengerling

23 Public Interest Litigation and Climate Change-An Example from Kenya

Collins Odote

24 Injunctions against Climate Change?

Ulrich Magnus

25 Climate Change and Liability: An Overview of Legal Issues Ina Ebert

\section{PART VI: INTERNATIONAL CLIMATE CHANGE LAW AND CROSSCUTTING ISSUES}

26 Limitations of Risk Law 
27 International Climate Law and Mining Regulation - Perspectives from Developing Countries

Yemi Oke

28 Legal and Regulatory Aspects of Carbon Capture and Storage:

A Developed and Developing Country Perspective

Jan Glazewski

29 Climate Change Mitigation and Adaptation: What is the Role of Intellectual Property and Traditional Knowledge?

Eliamani I. Laltaika \& Joy Faida

30 Climate Engineering and International Law: Final Exit or the End of Humanity?

Gerd Winter

Annex

Contents Volume II

Climate Change: International Law and Global Governance

Volume II: Policy, Diplomacy and Governance in a Changing

Environment 